Article

\title{
Whey Protein Drink Ingestion before Breakfast Suppressed Energy Intake at Breakfast and Lunch, but Not during Dinner, and Was Less Suppressed in Healthy Older than Younger Men
}

\author{
Avneet Oberoi ${ }^{1}$ (D), Caroline Giezenaar ${ }^{2}{ }^{\mathbb{D}}$, Alina Clames ${ }^{1}$, Kristine Bøhler $^{1}$, Kylie Lange ${ }^{1}$, \\ Michael Horowitz ${ }^{1}$, Karen L. Jones ${ }^{1}$ (D), Ian Chapman ${ }^{1}$ and Stijn Soenen ${ }^{1,3, *}$ \\ 1 Adelaide Medical School and Centre of Research Excellence in Translating Nutritional Science to Good \\ Health, The University of Adelaide, Adelaide, Royal Adelaide Hospital, Adelaide, \\ SA 5000, South-Australia, Australia; avneet.oberoi@adelaide.edu.au (A.O.); \\ alina.clames@adelaide.edu.au (A.C.); kristine.bohler@adelaide.edu.au (K.B.); \\ kylie.lange@adelaide.edu.au (K.L.); michael.horowitz@adelaide.edu.au (M.H.); \\ karen.jones@adelaide.edu.au (K.L.J.); ian.chapman@adelaide.edu.au (I.C.) \\ 2 Riddet Institute, Massey University, Palmerston North 9430, New Zealand; c.giezenaar@massey.ac.nz \\ 3 Faculty of Health Sciences \& Medicine, Bond University, Gold Coast 4229, Queensland, Australia \\ * Correspondence: stijn.soenen@adelaide.edu.au; Tel.: +61-487-333-418
}

Received: 24 September 2020; Accepted: 27 October 2020; Published: 29 October 2020

\begin{abstract}
Ageing is associated with changes in feeding behavior. We have reported that there is suppression of energy intake three hours after whey protein drink ingestion in young, but not older, men. This study aimed to determine these effects over a time period of $9 \mathrm{~h}$. Fifteen younger $(27 \pm 1$ years, $\left.25.8 \pm 0.7 \mathrm{~kg} / \mathrm{m}^{2}\right)$ and 15 older $\left(75 \pm 2\right.$ years, $\left.26.6 \pm 0.8 \mathrm{~kg} / \mathrm{m}^{2}\right)$ healthy men were studied on three occasions on which they received, in a randomized order, a $30 \mathrm{~g} / 120 \mathrm{kcal}, 70 \mathrm{~g} / 280 \mathrm{kcal}$ whey-protein, or control ( $2 \mathrm{kcal}$ ) drink. Ad-libitum energy intake (sum of breakfast, lunch, and dinner) was suppressed in a protein load responsive fashion $(P=0.001)$. Suppression was minimal at breakfast, substantial at lunch $(\sim-16 \%, P=0.001)$, no longer present by dinner, and was less in older than younger men $(-3 \pm 4 \%$ vs. $-8 \pm 4 \%, P=0.027)$. Cumulative protein intake was increased in the younger and older men $(+20 \%$ and $+42 \%, P<0.001)$. Visual analogue scale ratings of fullness were higher and desire to eat and prospective food consumption were lower after protein vs. control, and these effects were smaller in older vs. younger men (interaction effect $P<0.05$ ). These findings support the use of whey-protein drink supplements in older people who aim to increase their protein intake without decreasing their overall energy intake.
\end{abstract}

Keywords: whey protein; energy intake; gastric emptying; appetite

\section{Introduction}

The number of older people with malnutrition, both under- and over-nutrition, is rising [1]. Healthy ageing is associated with a reduction in appetite and food intake, including protein intake, which predisposes older people to loss of body weight and in particular, skeletal muscle mass [2,3]. The latter is associated with a decrease in function and quality of life [4]. The causes of the reduction in food intake during healthy ageing are likely to be heterogeneous, including changes in gastrointestinal mechanisms induced by nutrient intake, such as slowing of gastric emptying $[5,6]$.

A common strategy to increase energy intake and body weight in undernourished older people is the use of $>25-30 \mathrm{~g}$ whey protein-enriched supplements [7], which may result in preserved or even 
increased muscle mass and strength $[7,8]$. We reported that in healthy older adults, when compared to younger adults, the acute suppression (up to $3 \mathrm{~h}$ following ingestion) of energy intake by protein administered orally or infused directly into the duodenum is less, resulting in an increase of overall energy and protein intake in the older adults [9-11]. In healthy, younger adults, protein is considered to be the most satiating macronutrient and protein-rich supplements and diets are often recommended as a weight loss strategy in obese, younger individuals. There is a lack of definitive evidence on their efficacy [12,13], especially in older adults.

In this study, we aimed to characterize the effect of ageing on the suppression of food intake at breakfast, lunch, and dinner over a time period of $9 \mathrm{~h}$ by a pre-breakfast whey protein load ( $30 \mathrm{~g}$ and $70 \mathrm{~g}$ ) compared to a control drink in healthy younger and older men. We hypothesized that suppression of energy intake by whey protein when compared to control would be less in healthy older than younger adults, resulting in an increase in cumulative energy and protein intake in the older men.

\section{Materials and Methods}

\subsection{Subjects}

The study included 15 healthy younger men (mean \pm standard error of the mean (SEM) age: $27 \pm 1$ years; body weight: $76.1 \pm 2.0 \mathrm{~kg}$; height: $1.73 \pm 0.02 \mathrm{~m}$; body mass index (BMI): $25.8 \pm 0.7 \mathrm{~kg} / \mathrm{m}^{2}$ ) and 15 healthy older men ( $75 \pm 2$ years; $\left.80.7 \pm 2.9 \mathrm{~kg} ; 1.75 \pm 0.01 \mathrm{~m} ; 26.6 \pm 0.8 \mathrm{~kg} / \mathrm{m}^{2}\right)$. Body weight and BMI of the younger and older men did not differ significantly $(P>0.05)$. Subjects were recruited by online advertisement and by flyers placed on notice boards at the University of Adelaide, Adelaide, Australia.

Exclusion criteria included smoking; alcohol intake of $>2$ standard drinks on $>5$ days per week; being vegetarian; intake of any illicit substance; use of prescribed or non-prescribed medications that may affect appetite, body weight, gastrointestinal function, or energy metabolism; food allergy(s); diabetes mellitus (fasting glucose concentration $>6.9 \mathrm{mmol} / \mathrm{L}$ ); epilepsy; gallbladder, pancreatic, cardiovascular, or respiratory diseases; significant gastrointestinal symptoms, disease, or surgery; any other illness deemed significant by the investigator; and an inability to comprehend the study protocol. Inclusion criteria included being weight stable ( $<5 \%$ fluctuation in their body weight) at study entry, as assessed by their self-reported weight in the preceding 3 months, and maintenance of usual physical activity level.

All subjects gave written informed consent for inclusion before they participated in the study. The study was conducted in accordance with the Declaration of Helsinki and the protocol was approved by the Ethics Committee of The Royal Adelaide Hospital (HREC/18/CALHN/132) and registered under trial registration number ACTRN12618000881235.

\subsection{Protocol}

Each participant was studied on three occasions, separated by 3-10 days. On each occasion, they received, in a randomized order (using the method of randomly permuted blocks; www. randomization.com), a single drink of either flavoured water (control; $\sim 2 \mathrm{kcal}$ ), $30 \mathrm{~g}$ whey protein (120 $\mathrm{kcal})$, or $70 \mathrm{~g}$ whey protein $(280 \mathrm{kcal})$. The drinks were equivolaemic $(\sim 450 \mathrm{~mL})$ and contained different quantities of food-grade unflavoured whey protein isolate (Bulk Nutrients, Tasmania, Australia) dissolved in varying amounts of distilled water, sodium chloride, and low-calorie lime cordial (Bickford's "diet lime" cordial) [11].

Volunteers arrived at the laboratory at $\sim 8.00$ a.m. after fasting for $\sim 12 \mathrm{~h}$ overnight and refraining from strenuous exercise and alcohol for $24 \mathrm{~h}$. The subjects were provided with a standard meal the night before each study day (beef lasagne, McCain Foods Pty Ltd., Wendouree, VIC, Australia 591 kcal). Subjects were told that we were assessing perceptions of appetite around the 3 meals, but not that we measured their food/energy intake.

At baseline $(t=-5 \mathrm{~min})$, perceptions of appetite were assessed by visual analogue scales (VAS) and the antral area of the stomach $\left(\mathrm{cm}^{2}\right)$ was measured with a LogiqTM e-ultrasound machine 
(GE Healthcare Technologies, Sydney, NSW, Australia). Subsequently, the drink was administered at $\mathrm{t}=-2 \mathrm{~min}$ ( $\sim 8.30$ a.m.) and was served in an opaque cup to ensure that the volunteers were blinded. Participants were asked to ingest the drink within $2 \mathrm{~min}$. Following consumption of the drink $(\mathrm{t}=0 \mathrm{~min})$, palatability of the drink and perceptions of appetite were assessed by VAS. The antral area of the stomach was measured at several time points between the drink and breakfast $(t=0,5$, 20, $35 \mathrm{~min}$ ) and not thereafter. Energy intake was measured at breakfast $(\mathrm{t}=35-65 \mathrm{~min} ; \sim 9$ a.m. $)$, lunch $(\mathrm{t}=275-305 \mathrm{~min} ; \sim 1$ p.m. $)$, and dinner $(\mathrm{t}=515-545 \mathrm{~min} ; \sim 5$ p.m.). Breakfast and lunch consisted of a cold buffet-style meal (Table 1 ) and dinner consisted of a warm meal and a small variation of buffet items (Table 2). Subjects were instructed to consume food until they were comfortably full. Before and after consumption of the meals, perceptions of appetite, in terms of hunger, fullness, desire to eat, and prospective food consumption, were assessed $(t=0,5,20,35,65,80,95,275,305,320,335,515$, $545,560,575 \mathrm{~min})$. Subjects were not permitted to consume any food or drink between ingesting the study drink and the end of the study day, except at the breakfast, lunch, and dinner meals provided during the study day. Water intake in between meals was allowed, but not within 30 min before their next meal.

Table 1. Composition of the cold buffet-style breakfast and lunch meal.

\begin{tabular}{|c|c|c|c|c|c|}
\hline Food Items & $\begin{array}{c}\text { Amount Served } \\
\text { (g) }\end{array}$ & $\begin{array}{c}\text { Energy Content } \\
\text { (kcal) }\end{array}$ & $\begin{array}{l}\text { Protein } \\
\text { (g) }\end{array}$ & $\begin{array}{c}\text { Carbohydrate } \\
\text { (g) }\end{array}$ & $\begin{array}{l}\text { Fat } \\
\text { (g) }\end{array}$ \\
\hline Whole meal bread, 4 slices * & 125 & 308 & 13.8 & 54.8 & 4.9 \\
\hline White bread, 4 slices * & 125 & 304 & 11.1 & 61.4 & 2.7 \\
\hline Cheese, sliced ${ }^{\dagger}$ & 85 & 346 & 22.6 & 0.9 & 29.2 \\
\hline Ham, sliced $\ddagger$ & 100 & 95 & 17.1 & 3.5 & 1.8 \\
\hline Chicken, sliced $\S$ & 100 & 104 & 19.4 & 3.7 & 1.7 \\
\hline Margarine $\|$ & 20 & 108 & 0.0 & 0.0 & 12.4 \\
\hline Mayonnaise $\mathbb{I}$ & 20 & 137 & 0.4 & 0.7 & 15.2 \\
\hline Tomato, sliced & 100 & 13 & 1.0 & 2.0 & 0.1 \\
\hline Cucumber, sliced & 100 & 11 & 0.5 & 2.0 & 0.1 \\
\hline Lettuce & 100 & 5 & 0.9 & 0.4 & 0.0 \\
\hline Apple & 170 & 89 & 0.5 & 2.0 & 0.1 \\
\hline Banana & 190 & 166 & 3.3 & 39.0 & 0.2 \\
\hline Fruit salad ${ }^{* *}$ & 140 & 81 & 0.4 & 17.7 & 1.3 \\
\hline Strawberry yogurt ${ }^{+\dagger}$ & 175 & 162 & 9.1 & 25.0 & 3.4 \\
\hline Chocolate custard 㧊 & 100 & 105 & 3.3 & 16.9 & 3.1 \\
\hline Milky Way $\S \S$ & 12 & 52 & 0.3 & 9.0 & 1.9 \\
\hline Orange juice, unsweetened IIII & 300 & 117 & 1.9 & 22.6 & 2.7 \\
\hline Iced coffee IIII & 375 & 254 & 12.4 & 38.3 & 6.6 \\
\hline Water & 600 & 0 & 0.0 & 0.0 & 0.0 \\
\hline Total & & 2457 & $19 \%$ & $49 \%$ & $32 \%$ \\
\hline
\end{tabular}

* Sunblest, Tiptop, George Weston Foods Ltd., Enfield, NSW, Australia. ${ }^{\dagger}$ Coon Tasty Cheese slices, Australian Cooperative Foods Ltd., Sydney Olympic Park, NSW, Australia. ‡ KR Castlemaine boneless leg ham, George Weston Foods Ltd., Enfield, NSW, Australia. \$ Inghams chicken breast, Inghams Enterprises Pty Ltd., Burton, SA, Australia. "I Vita-Lite canola, Peerless Holdings Pty Ltd., Braybook, VIC, Australia. II MasterFoods, Mars Food Australia, Berkeley Vale, NSW, Australia. ** Goulburn Valley, SPC, Ardmona Operations Ltd., Shepparton, VIC, Australia.


Australia. \$\& Mars Chocolate Australia, Wendouree, VIC, Australia. IIII Golden Circle Orange juice, Golden Circle Limited, QLD, Australia. IIII Farmers Union, LD\&D Foods Pty Ltd., Docklands, VIC, Australia. 
Table 2. Composition of the dinner meal.

\begin{tabular}{|c|c|c|c|c|c|}
\hline Food Items & $\begin{array}{c}\text { Amount Served } \\
\text { (g) }\end{array}$ & $\begin{array}{c}\text { Energy Content } \\
\text { (kcal) }\end{array}$ & $\begin{array}{l}\text { Protein } \\
\text { (g) }\end{array}$ & $\begin{array}{c}\text { Carbohydrate } \\
\text { (g) }\end{array}$ & $\begin{array}{l}\text { Fat } \\
(\mathrm{g})\end{array}$ \\
\hline Pasta with Meatballs ${ }^{a}$ & 500 & 720 & 27.7 & 78.4 & 35.0 \\
\hline Whole meal bread, 4 slices * & 125 & 308 & 14.0 & 55.5 & 4.9 \\
\hline Margarine $\|$ & 20 & 108 & 0.0 & 0.0 & 12.5 \\
\hline Philadelphia cream cheese ${ }^{o}$ & 68 & 175 & 3.8 & 2.1 & 17.3 \\
\hline Apple & 170 & 89 & 0.5 & 2.0 & 0.1 \\
\hline Banana & 190 & 166 & 3.3 & 39.5 & 0.2 \\
\hline Fruit salad $* *$ & 140 & 81 & 0.4 & 17.9 & 1.4 \\
\hline Strawberry yogurt ${ }^{+\dagger}$ & 175 & 162 & 9.2 & 25.3 & 3.4 \\
\hline Chocolate custard 㧊 & 100 & 105 & 3.3 & 17.1 & 3.1 \\
\hline Muesli bar $^{3}$ & 35 & 185 & 5.6 & 12.5 & 13.1 \\
\hline Orange juice, unsweetened IIII & 300 & 117 & 1.9 & 22.9 & 2.7 \\
\hline Water & 600 & 0 & 0.0 & 0.0 & 0.0 \\
\hline Total & & 2216 & $13 \%$ & $49 \%$ & $38 \%$ \\
\hline
\end{tabular}

${ }^{\circ}$ Man Size Spaghetti and Meatballs, McCain Foods Pty Ltd., Wendouree, VIC, Australia. * Sunblest, Tiptop, George Weston Foods Ltd., Enfield, NSW, Australia. "Vita-Lite canola, Peerless Holdings Pty Ltd., Braybook, VIC, Australia. ${ }^{\circ}$ Philadelphia Spreadable Cream Cheese snack tubs, Consumer Advisory Service, Melbourne, VIC, Australia. ${ }^{* *}$ Goulburn Valley, SPC, Ardmona Operations Ltd., Shepparton, VIC, Australia. ${ }^{+\dagger}$ Yoplait, LD\&D Foods

Pty Ltd., Docklands, VIC, Australia. 㧊 Yogo, LD\&D Foods Pty Ltd., Docklands, VIC, Australia. ${ }^{\ni}$ Coles Nut bars, choc coated, Coles Supermarkets Australia Pty Ltd., Hawthorn East, VIC, Australia. IIII Golden Circle Orange juice, Golden Circle Limited, QLD, Australia.

\subsection{Measurements}

The primary outcome of the study was ad libitum energy intake at the buffet-style meal and secondary outcomes include antral area and appetite.

\subsubsection{Energy Intake}

To quantify the amount eaten, the weights of the food items were recorded before and after they was offered to the subjects [11]. Energy intake and macronutrient composition was calculated using commercially available software (Foodworks 3.01, Xyris Software, Highgate Hill, QLD, Australia). Absolute (kcal) and percentage suppression of energy intake (expressed as \% of energy intake of the control day) by protein were calculated.

\subsubsection{Antral Area}

Gastric emptying (gastric retention) was determined by measuring the antral area of the stomach. The circumference of the antral area was measured with a LogiqTM e-ultrasound machine (GE Healthcare Technologies, Sydney, NSW, Australia) by using a 3.5 C broad spectrum $2.5-4 \mathrm{MHz}$ convex linear array transducer. Antral area $\left(\mathrm{cm}^{2}\right)$ was determined with the use of a caliper and calculation program built into the ultrasound machine. Volunteers were seated on a chair and were asked to be still during the measurement. The transducer was positioned vertically to obtain a parasagittal image of the antrum, with the superior mesenteric vein and the abdominal aorta in a longitudinal section. If gastric contractions were observed, the acquisition was paused until the contraction wave had passed. To calculate meal retention in the whole stomach, the fasting antral area (measured at baseline) was subtracted from subsequent measurements performed after ingestion of the drinks [14]. Gastric retention was then calculated at a given time point as:

$$
\text { Retention }(\%)=[\mathrm{AA}(\mathrm{t})-\mathrm{AA}(\mathrm{f})] /[\mathrm{AA}(\max )-\mathrm{AA}(\mathrm{f})] \times 100 \text {, }
$$

where $\mathrm{AA}(\mathrm{t})=$ antral area measured at a given time point, $\mathrm{AA}(\mathrm{f})=$ fasting antral area, and $\mathrm{AA}(\max )=$ maximum antral area recorded after drink ingestion [11]. 


\subsubsection{Perceptions of Appetite and Palatability}

Perceptions of appetite in terms of hunger, fullness, desire to eat, and prospective consumption were assessed by use of a VAS questionnaire [15]. The questionnaire consisted of $100 \mathrm{~mm}$ horizontal lines, where 0 represented that the sensation was "not felt at all" and 100 represented that the sensation was "felt the greatest." Volunteers placed a vertical mark on each horizontal line to signify the strength of each sensation at the specified time points. Baseline fasting ratings were calculated as the mean of the three study days. Total AUC was calculated over 0-180 min [11].

Palatability of the drink was assessed by ratings of pleasantness, intenseness, full of taste, sweetness, saltiness, sour, bitterness, umami, and creaminess immediately after drink intake; palatability of the meal was assessed by like of taste, like of aftertaste, and enjoyability of the meal by use of a VAS questionnaire.

\subsection{Data and Statistical Analysis}

Statistical analyses were performed using SPSS software (version 24; IBM, Armonk, NY, USA). Power calculations were performed for the primary outcome of energy intake using measures of variance obtained from previous data (SD of $181 \mathrm{kcal}$ ) [11] to detect a minimum difference in suppression of energy intake by the treatment condition compared with the control of $251 \mathrm{kcal}$ between younger and older subjects. Age and protein load main effects and the age by protein load interaction on outcomes were determined by using two-way repeated-measures analysis of variance (ANOVA). Residuals from all models were checked for normality and constant variance and all assumptions were found to be met. When significant treatment and/or interaction effects were present, Bonferroni corrected post hoc tests were performed to determine which specific drink conditions were different between age groups. Statistical significance was accepted at $P<0.05$. All data are presented as means \pm SEMs.

\section{Results}

The study protocol was well tolerated by all subjects.

\subsection{Energy Intake}

Energy intake after the drink (sum of breakfast, lunch, and dinner; Figure 1) was suppressed by whey protein compared to control (protein load main effect on energy intake $P=0.012$ ), driven by the suppression of the $70 \mathrm{~g}$ whey protein drink (young: $-251 \pm 117 \mathrm{kcal},-8 \pm 4 \%$; older: $-184 \pm 96 \mathrm{kcal}$, $-5 \pm 4 \%$; post-hoc test $P=0.023)$, which was greater $(P=0.027)$ when compared with the 30 g protein drink (young: $-88 \pm 108 \mathrm{kcal},-3 \pm 4 \%$; older: $-5 \pm 99 \mathrm{kcal}, 0 \pm 4 \%$; Table 3). Suppression of energy intake by the $70 \mathrm{~g}$ whey protein compared to control (protein load main effect, $P=0.007$ ) was greatest at lunch (young: $-181 \pm 83 \mathrm{kcal},-17 \pm 8 \%$; older: $-154 \pm 49 \mathrm{kcal},-15 \pm 5 \% ; P=0.001$; Figure 2). Protein intake of the drink, before breakfast, did not affect ad libitum energy intake at dinner in either age group. Suppression of energy intake (sum of breakfast, lunch, and dinner) by whey protein was less in healthy older men: $-94 \pm 82 \mathrm{kcal}$ when compared to younger men $-169 \pm 100 \mathrm{kcal}$ (there was a main effect of age on suppression of energy intake by protein compared to control $P=0.027$ ).

Cumulative energy intake (sum of energy in test drink, breakfast, lunch, and dinner) was not significantly different between study days and age groups (young: control: $2929 \pm 131 \mathrm{kcal}, 30 \mathrm{~g}$ whey protein: $2961 \pm 161 \mathrm{kcal}$ and $70 \mathrm{~g}$ whey protein: $2958 \pm 163 \mathrm{kcal}$; older: $2878 \pm 165 \mathrm{kcal}, 2993 \pm 122 \mathrm{kcal}$ and $2974 \pm 148 \mathrm{kcal}$, all $P>0.05)$. 

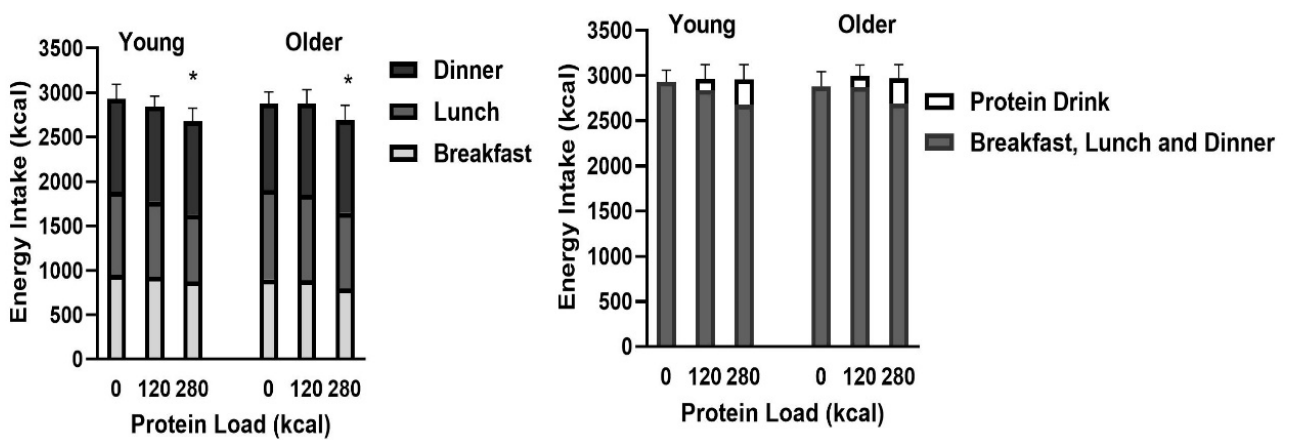

Figure 1. Energy intake at breakfast, lunch, and dinner following whey protein ingestion in healthy young and older men. Mean $( \pm$ SEM) ad libitum energy intake (kcal; left) at breakfast (light grey bars), lunch (dark grey bars), and dinner (black bars) following drink ingestion containing flavored water (control, $\sim 2 \mathrm{kcal}$ ) or whey protein $(30 \mathrm{~g} / 120 \mathrm{kcal}$ or $70 \mathrm{~g} / 280 \mathrm{kcal}$ ) and cumulative energy intake (kcal; right; sum total energy intake at breakfast, lunch, and dinner combined (dark grey bars) and protein drink (white bars)) in young (left; $n=15$ ) and older (right; $n=15)$ men. Age and protein load main effects and interaction effects were determined by repeated measures ANOVA. * The 70 g protein drink suppressed energy intake (sum of breakfast, lunch, and dinner) compared with the control (protein load effect $P=0.012$, post-hoc $P=0.023$ ).
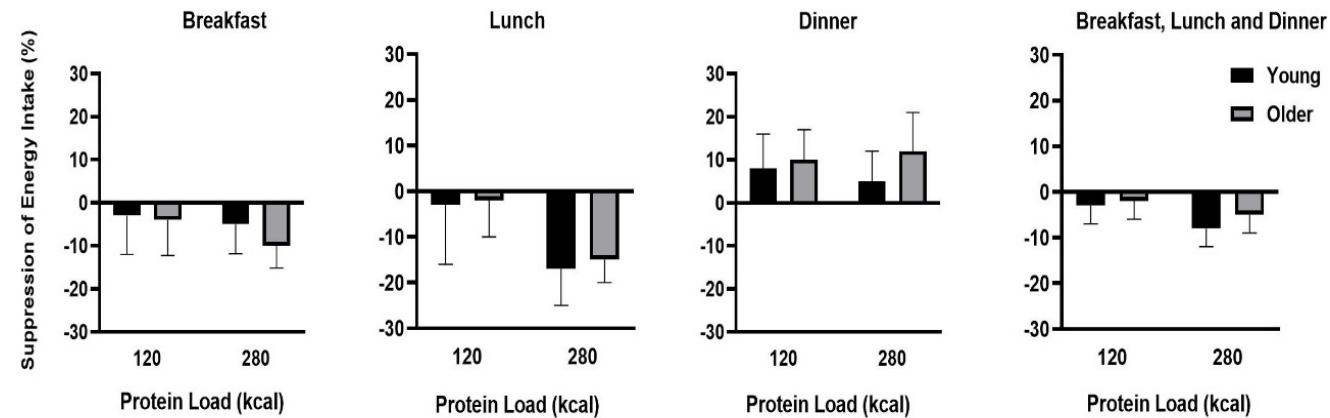

Figure 2. Suppression of energy intake by whey protein at breakfast, lunch, and dinner and total suppression of energy intake in healthy young and older men. Mean $( \pm$ SEM) suppression of energy intake (kcal) at breakfast, lunch, and dinner following whey protein $(30 \mathrm{~g} / 120 \mathrm{kcal}$ or $70 \mathrm{~g} / 280 \mathrm{kcal})$ ingestion compared to control $(\sim 2 \mathrm{kcal})$ in young (black shading; $n=15)$ and older (grey shading; $n=15$ ) men. Age and protein load main effects and interaction effects were determined by using repeated-measures ANOVA. Energy intake was suppressed by protein (protein load main effect $P=0.012$ ). Suppression of energy intake by $70 \mathrm{~g}$ protein $(P=0.007)$ was evident, particularly at lunch $(P=0.001)$. Suppression of energy intake (sum of breakfast, lunch, and dinner) by protein was less in healthy older than younger men (main effect of age $P=0.027$ ). 
Table 3. Energy intake at and macronutrient composition of breakfast, lunch, and dinner following whey protein drink ingestion in healthy young and older men.

\begin{tabular}{|c|c|c|c|c|c|c|c|c|}
\hline & \multicolumn{3}{|c|}{ Young $(n=15)$} & \multicolumn{5}{|c|}{ Older $(n=15)$} \\
\hline & Breakfast & Lunch & Dinner & Total & Breakfast & Lunch & Dinner & Total \\
\hline \multicolumn{9}{|l|}{ Control drink } \\
\hline Energy intake (kcal) & $947 \pm 64$ & $933 \pm 74$ & $1049 \pm 68$ & $2929 \pm 131$ & $896 \pm 74$ & $1007 \pm 62$ & $975 \pm 79$ & $2878 \pm 165$ \\
\hline Fat (energy \%) & $34 \pm 1$ & $34 \pm 2$ & $36 \pm 2$ & & $29 \pm 2$ & $33 \pm 6$ & $39 \pm 2$ & \\
\hline Carbohydrate (energy \%) & $43 \pm 2$ & $43 \pm 2$ & $50 \pm 2$ & & $51 \pm 2$ & $46 \pm 2$ & $47 \pm 2$ & \\
\hline Protein (energy \%) & $23 \pm 1$ & $23 \pm 1$ & $14 \pm 1$ & & $20 \pm 1$ & $21 \pm 1$ & $14 \pm 1$ & \\
\hline \multicolumn{9}{|c|}{$30 \mathrm{~g}$ (120kcal) protein drink } \\
\hline Energy intake (kcal) & $925 \pm 67$ & $848 \pm 89$ & $1068 \pm 48$ & $2841 \pm 161$ & $888 \pm 60$ & $962 \pm 84$ & $1023 \pm 66$ & $2873 \pm 122$ \\
\hline Fat (energy \%) & $34 \pm 2$ & $30 \pm 3$ & $38 \pm 2$ & & $30 \pm 1$ & $34 \pm 1$ & $38 \pm 2$ & \\
\hline Carbohydrate (energy \%) & $43 \pm 2$ & $48 \pm 4$ & $47 \pm 1$ & & $51 \pm 3$ & $46 \pm 2$ & $48 \pm 1$ & \\
\hline Protein (energy \%) & $23 \pm 1$ & $22 \pm 2$ & $15 \pm 0$ & & $19 \pm 1$ & $20 \pm 1$ & $14 \pm 1$ & \\
\hline \multicolumn{9}{|c|}{$70 \mathrm{~g}(280 \mathrm{kcal})$ protein drink } \\
\hline Energy intake (kcal) & $874 \pm 70$ & $752 \pm 85 *$ & $1052 \pm 56$ & $2678 \pm 163$ & $794 \pm 72$ & $853 \pm 69 *$ & $1047 \pm 82$ & $2694 \pm 148$ \\
\hline Fat (energy \%) & $34 \pm 1$ & $27 \pm 2$ & $48 \pm 2$ & & $30 \pm 2$ & $32 \pm 1$ & $38 \pm 2$ & \\
\hline Carbohydrate (energy \%) & $43 \pm 2$ & $54 \pm 3$ & $47 \pm 1$ & & $51 \pm 4$ & $46 \pm 2$ & $48 \pm 1$ & \\
\hline Protein (energy \%) & $23 \pm 1$ & $19 \pm 2$ & $15 \pm 0$ & & $19 \pm 1$ & $22 \pm 1$ & $14 \pm 0$ & \\
\hline
\end{tabular}

Mean ( \pm SEM) ad libitum energy intake (kcal) at and macronutrient composition (energy percentage) of breakfast, lunch, and dinner, following drink ingestion containing flavoured water (control, $\sim 2 \mathrm{kcal}$ ) or whey protein $(30 \mathrm{~g} / 120 \mathrm{kcal}$ or $70 \mathrm{~g} / 280 \mathrm{kcal})$ in young (left; $n=15)$ and older (right; $n=15)$ men. Age and protein load main effects and interaction effects were determined by using repeated-measures ANOVA. * Energy intake was suppressed by protein compared to control (protein load main effect $P=0.012$ ). Suppression of energy intake by $70 \mathrm{~g}$ protein compared to control $(P=0.007)$ occurred particularly during lunch $(P=0.001)$ 


\subsection{Protein Intake}

1. The sum of breakfast, lunch, and dinner protein intake after the test drinks decreased after the $70 \mathrm{~g}(P=0.023)$, but not $30 \mathrm{~g}$, whey protein drink when compared to the control day (protein load main effect $P=0.009$, main effect of age $P=0.71$, interaction effect $P=0.54$ ).

2. Cumulative protein intake (sum of protein in the drink plus protein intake at the meals) was increased in a protein load responsive fashion (young: control: $143 \pm 10 \mathrm{~g}$, $30 \mathrm{~g}$ whey protein: $+17 \%, 167 \pm 9 \mathrm{~g}$ and $70 \mathrm{~g}$ whey protein: $+36 \%, 195 \pm 9 \mathrm{~g}$; older: control: $133 \pm 10 \mathrm{~g}$, $30 \mathrm{~g}$ whey protein: $+23 \%, 164 \pm 10 \mathrm{~g}$ and $70 \mathrm{~g}$ whey protein: $+47 \%, 195 \pm 9 \mathrm{~g} ; \mathrm{P}<0.001)$ comparably in the healthy younger and older men (main effect of age $P=0.71$, interaction effect of age $x$ protein load $P=0.54$; Figure 3).



Figure 3. Mean ( \pm SEM) protein intake $(g)$ at breakfast (light grey bars), lunch (dark grey bars), and dinner (black bars) following drink ingestion containing flavored water (control, $\sim 2 \mathrm{kcal}$ ) or whey protein (30 g/120 kcal or $70 \mathrm{~g} / 280 \mathrm{kcal}$; white bars) in young (left; $n=15)$ and older (right; $n=15)$ men. Age and protein load main effects and interaction effects were determined by using repeated-measures ANOVA. * Cumulative protein intake (sum of protein drink plus protein intake at meals) was increased in a protein load responsive fashion comparably in the healthy young and older men (main effect of age $P=0.71$, protein load main effect $P<0.001$, interaction effect $P=0.54$ ).

\subsection{Gastric Emptying}

Antral areas following overnight fasting (control: $3.4 \pm 0.8 \mathrm{~cm}^{2} ; 30 \mathrm{~g}$ whey protein: $2.8 \pm 0.7 \mathrm{~cm}^{2}$; $70 \mathrm{~g}$ whey protein: $2.9 \pm 0.8 \mathrm{~cm}^{2}$; protein load main effect $P=0.21$ ) and immediately after drink consumption (control: $15.6 \pm 0.8 \mathrm{~cm}^{2} ; 30 \mathrm{~g}$ whey protein: $16.2 \pm 0.8 \mathrm{~cm}^{2} ; 70 \mathrm{~g}$ whey protein: $16.4 \pm 0.8 \mathrm{~cm}^{2}$; protein load main effect $\left.P=0.76\right)$ were comparable between the study days for both the age groups. Gastric retention was greater after both protein drinks compared to control (main effect of age $P=0.27$, protein load main effect $P<0.001$, interaction effect $P=0.091$; Figure 4 ). 
Young

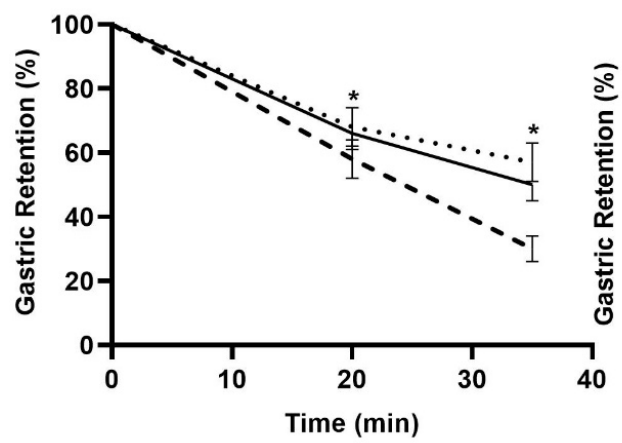

Older

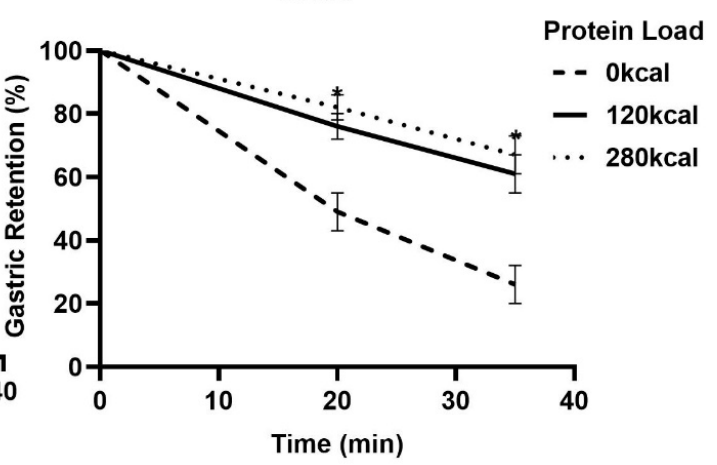

Figure 4. Mean ( \pm SEM) Gastric Retention (\%) of drinks containing flavored water (control, $\sim 2 \mathrm{kcal}$ ) or whey protein (30 g/120 kcal or $70 \mathrm{~g} / 280 \mathrm{kcal}$; open bars) in young (left; $n=15)$ and older (right; $n=15)$ men. Age and protein load main effects and interaction effects were determined by using repeated-measures ANOVA. * Gastric Retention, calculated based on the antral areas, were larger after both protein drinks compared to control (main effect of age $P=0.27$, protein main effect $P<0.001$, interaction effect $P=0.091$ ).

\subsection{Appetite}

Baseline perceptions of appetite in terms of hunger (young: $61 \pm 8 \mathrm{~mm}$; older: $59 \pm 9 \mathrm{~mm}$ ), fullness $(13 \pm 4 \mathrm{~mm} ; 5 \pm 2 \mathrm{~mm})$, desire to eat $(61 \pm 7 \mathrm{~mm} ; 52 \pm 8 \mathrm{~mm})$, and prospective food consumption $(67 \pm 5 \mathrm{~mm} ; 55 \pm 6 \mathrm{~mm})$ were not significantly different between study days and age groups after overnight fasting (all $P>0.05$ ). Protein drink ingestion affected fullness (protein main effect $P<0.001$ ), desire to eat $(P<0.001)$, and prospective food consumption $(P=0.002$; Figure 5$)$ in a protein load related fashion; fullness was higher (AUC, both $P<0.001$ ) and desire to eat (AUC, $P=0.035$ and $P=0.009$ ) and prospective food consumption (immediately before lunch, $P=0.025, P=0.006$ ) were lower after the $70 \mathrm{~g}$ whey protein drink compared to control and the $30 \mathrm{~g}$ protein drink. Older compared to younger men had a lesser desire to eat (main effect of age $P=0.028$ ) but also less fullness (main effect of age $P=0.003$, interaction effect of age $\mathrm{x}$ protein load $P<0.001$ ) throughout the day (Figure 5 ). 

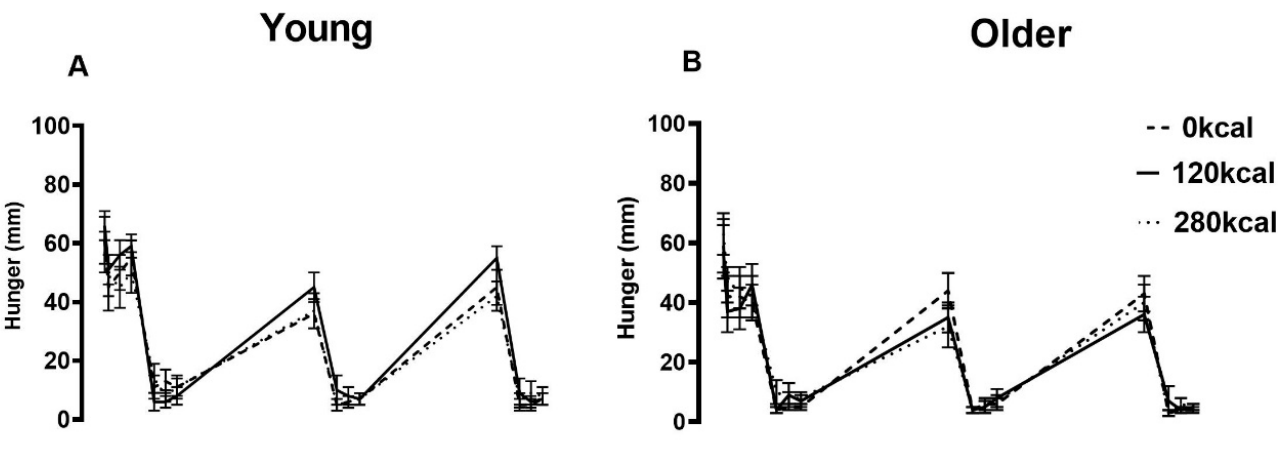

C

D
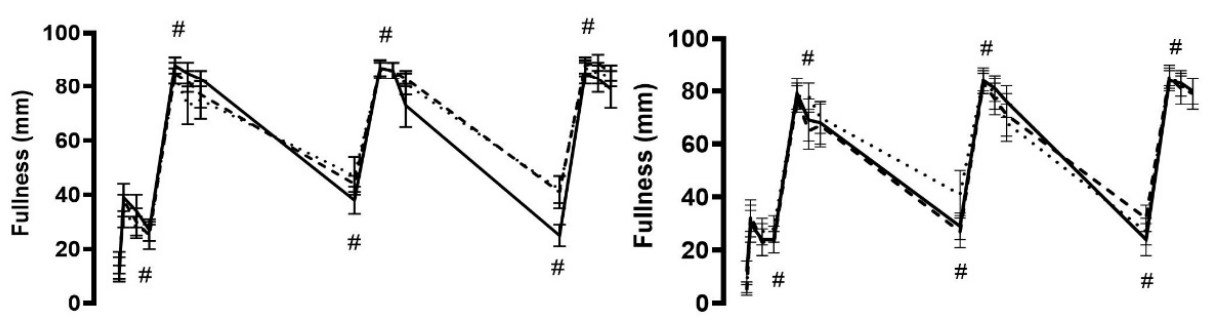

E

F
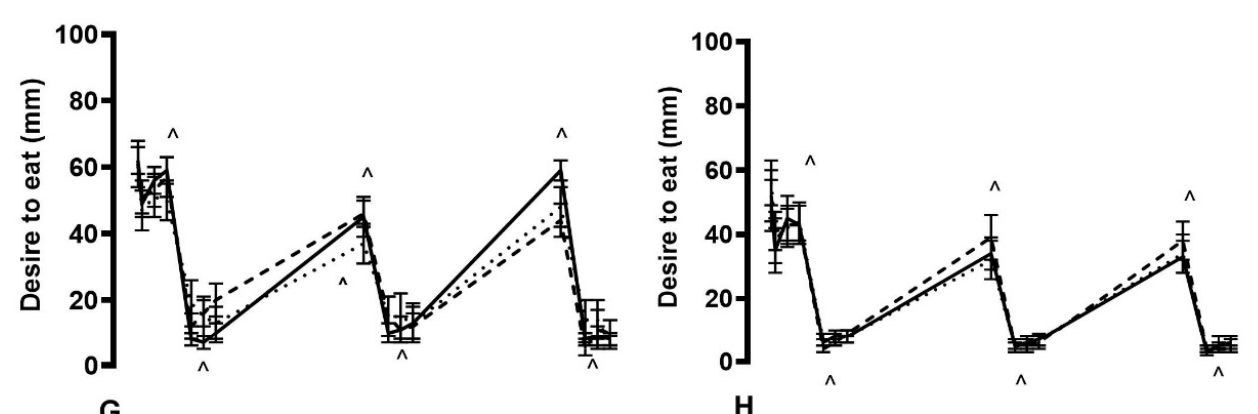

G
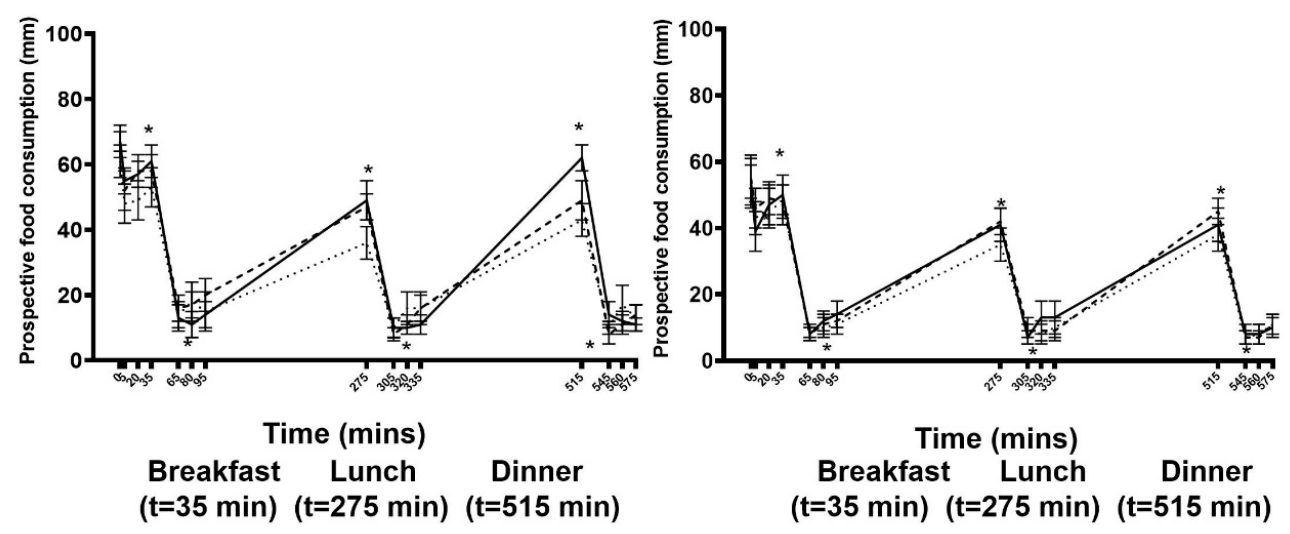

Figure 5. Mean ( \pm SEM) visual analogue scores (VAS; 0-545 min) of hunger $(\mathbf{A}, \mathbf{B})$, fullness $(\mathbf{C}, \mathbf{D})$, desire to eat $(\mathbf{E}, \mathbf{F})$, and prospective food consumption $(\mathbf{G}, \mathbf{H})$ following overnight fasting $(t=-5)$ and after drink ingestion $(t=0,5,20,35,65,80,95,275,305,320,335,515,545,560,575 \mathrm{~min})$ containing flavored water (control, $\sim 2 \mathrm{kcal}$ ) or whey protein $(30 \mathrm{~g} / 120 \mathrm{kcal}$ or $70 \mathrm{~g} / 280 \mathrm{kcal}$; open bars) and immediately before and after breakfast (B), lunch (L), and dinner (D) in young (left; $n=15)$ and older (right; $n=15$ ) men. Age and protein load main effects and interaction effects were determined using repeated-measures ANOVA. Protein affected " fullness (protein load main effect $P<0.001$ ), ^ desire to eat $(P<0.001)$, and * prospective food consumption $(P=0.002)$ in a protein load related fashion. Older compared to younger men had lower desire to eat (main effect of age $P=0.028$ ) and fullness $(P=0.003$, interaction effect $P<0.001)$. 


\subsection{Palatability of Drinks and Meals}

The $70 \mathrm{~g}$ whey protein drink was perceived to be creamier when compared to the flavored control drink $(P=0.016)$. Ratings of pleasantness, intenseness, full of taste, sweetness, saltiness, sour, bitterness, umami, and creaminess of the drinks were not significantly different (main effect of protein $P>0.05$ ). The healthy younger men rated the drinks as more bitter than the older men (young: $19 \pm 4 \mathrm{~mm}$; older: $26 \pm 3 \mathrm{~mm}$, main effect of age $P=0.037$ ). All other palatability ratings of the drinks were comparable between the age groups: pleasant (young: $47 \pm 5 \mathrm{~mm}$; older: $44 \pm 4 \mathrm{~mm}$ ), intense ( $51 \pm 4 \mathrm{~mm} ; 55 \pm 3 \mathrm{~mm}$ ), fullness ( $59 \pm 4 \mathrm{~mm} ; 59 \pm 3 \mathrm{~mm})$, sweet $(53 \pm 3 \mathrm{~mm} ; 48 \pm 3 \mathrm{~mm}$ ), salty $(31 \pm 6 \mathrm{~mm} ; 37 \pm 4 \mathrm{~mm})$, sour $(34 \pm 6 \mathrm{~mm} ; 39 \pm 4 \mathrm{~mm})$, umami $(34 \pm 5 \mathrm{~mm} ; 35 \pm 3 \mathrm{~mm})$, refreshing ( $40 \pm 6 \mathrm{~mm} ; 41 \pm 4 \mathrm{~mm}$ ), creaminess $(27 \pm 5 \mathrm{~mm} ; 31 \pm 3 \mathrm{~mm}$, main effect of age all $P>0.05)$. Palatability of the meals, assessed as ratings of taste, aftertaste, and enjoyability, were comparable between study days and age groups (control, $30 \mathrm{~g}, 70 \mathrm{~g}$ protein: young: taste: $73 \pm 5 \mathrm{~mm}, 75 \pm 5 \mathrm{~mm}, 72 \pm 6 \mathrm{~mm}$, after taste: $73 \pm 5 \mathrm{~mm}, 72 \pm 5 \mathrm{~mm}, 73 \pm 5 \mathrm{~mm}$, enjoyable: $73 \pm 5 \mathrm{~mm}, 75 \pm 5 \mathrm{~mm}, 74 \pm 5 \mathrm{~mm}$; older: taste: $72 \pm 4 \mathrm{~mm}, 74 \pm 3 \mathrm{~mm}, 72 \pm 4 \mathrm{~mm}$, after taste: $71 \pm 3 \mathrm{~mm}, 71 \pm 3 \mathrm{~mm}, 72 \pm 4 \mathrm{~mm}$, enjoyable: $73 \pm 4 \mathrm{~mm}$, $76 \pm 3 \mathrm{~mm}, 73 \pm 4 \mathrm{~mm}$; main effects of age, protein load main effects and interaction effects all $P>0.05$ ).

\section{Discussion}

This study compared the acute effects of ingestion of whey protein drinks containing $30 \mathrm{~g}$ and $70 \mathrm{~g}$ to those of a flavored control drink consumed $35 \mathrm{~min}$ before breakfast on ad libitum energy intake at breakfast, lunch, and dinner, perceptions of appetite throughout the day, and gastric emptying (antral area) in healthy younger and older men. Energy intake (sum of breakfast, lunch, and dinner) was suppressed in a protein load-responsive fashion at breakfast and in particular, at lunch, but not at dinner. Suppression of combined energy intake at breakfast, lunch, and dinner by the protein drink was less in healthy older $(-3 \%)$ when compared to younger $(-7 \%)$ men. Cumulative protein intake (sum of protein drink plus protein intake at the meals) was increased in a protein load responsive fashion $(+20 \%$ and $+42 \%)$ in the healthy younger and older men. Gastric emptying of the protein drinks in the $35 \mathrm{~min}$ before breakfast was slower than that of the control. Fullness was higher and desire to eat and prospective food consumption lower after protein intake when compared with the control in a protein load related fashion. Older compared to younger men had a lower desire to eat but also lower fullness throughout the day, suggesting that older people experience lower sensitivity of the appetite-suppressing effects of a protein drink and may have a decreased perception of gastric distension as seen in our previous study $[16,17]$.

Overall, suppression of energy intake by protein was less in healthy older than younger men in this study, confirming the results of our previous studies [11,18-21], e.g., in a study with a comparable design, suppression of energy intake by oral whey protein ingestion was $\sim-15 \%$ in healthy young compared to $\sim-1 \%$ in older men. In the present study, energy intake (sum of breakfast, lunch, and dinner) was suppressed most by the $70 \mathrm{~g}$ whey protein load compared to control ( $7 \%)$ and at lunch, $4 \mathrm{~h} 35 \mathrm{~min}$ after the drink ( $-20 \%$ in young and $\sim-15 \%$ in older men). In contrast, there was no suppression of energy intake by pre-breakfast protein at dinner time, $8 \mathrm{~h} 35 \mathrm{~min}$ after the drink, in either age group $(\sim+7 \%$ compared to control dinner). We reported previously that in healthy older people, the timing of a $30 \mathrm{~g}$ whey protein drink $(3 \mathrm{~h}, 2 \mathrm{~h}, 1 \mathrm{~h}$, and immediately before the buffet-style meal) does not affect subsequent energy intake in older people. The effect of the whey protein ingestion on energy intake throughout the day may be associated with the slightly slower gastric emptying, reported by us and others in previous studies measuring gastric emptying for a period of $3 \mathrm{~h}$ in healthy older, when compared with younger, people [11,18-20]. Gastric emptying may be associated with postprandial satiety by affecting plasma gut hormone concentrations [22] in healthy younger adults $[14,16,23,24]$.

The cumulative energy intake (sum of drink, breakfast, lunch, and dinner) was comparable between study days while cumulative protein intake was elevated during the protein conditions in both age groups. Cumulative energy intake on the protein days compared to control was slightly 
higher in older $(+4 \%)$ than younger men $(-1 \%)$, as was reported in our previous studies determining ad libitum energy intake $3 \mathrm{~h}$ after oral whey protein ingestion [11] and following $1 \mathrm{~h}$ whey protein infusions directly into the small intestine [9]. The insignificant effect of the whey drink on cumulative daily energy intake in this study may indicate that the ingestion of a single daily dose of whey protein, in doses up to $70 \mathrm{~g}$, is unlikely to be a successful weight loss strategy to achieve a negative energy balance, without taking the effects on energy expenditure and muscle anabolism into account. Even if whey protein was given more than once a day, we have no evidence that this would have resulted in a greater cumulative energy deficit, particularly in older adults. The energy content of the protein drink would have equalled or outweighed suppression of energy intake produced by the protein drink. Given our finding with one protein drink before breakfast, it is likely that suppression of cumulative energy intake with multiple drinks would have been even less [25]. The subjects in this study were not aware, however, that we were interested in or measuring their ad libitum meal energy intake throughout the day in response to the different drinks. Young adults using protein supplements to lose weight may have different responses to those in this study. Cumulative protein intake was significantly increased by the $30 \mathrm{~g}$ and $70 \mathrm{~g}$ whey protein loads, particularly in the older men (young: $+17 \%$ and $+36 \%$ and older: $+23 \%$ and $+47 \%$ ), reaching meaningful amounts sufficient to result in postprandial muscle anabolism in older adults $[8,26]$ - the $70 \mathrm{~g}$ whey protein drink increased protein intake by $62 \mathrm{~g}$, or $\sim 0.8 \mathrm{~g} / \mathrm{kg}$ body weight, in the older men.

A limitation of the study was that we only studied men. This was to enable comparisons with the results of our previous studies conducted in men which clearly showed the effect of protein load. As men generally show greater variations in appetite and food intake in response to energy manipulation than women $[27,28]$, the effects of the protein drinks may be different in women and it would be appropriate to perform further studies including women. The healthy older participants were well nourished, unrestrained eaters, had an active lifestyle, and comparable energy intake on the control day to the younger men. It has been reported numerous times that healthy ageing is associated with reduced food intake $[21,29]$ and hunger $[21,30,31]$ and a blunting of the regulation of food intake $[27,32]$ as suggested by the findings of this study, i.e., less suppression of energy intake by protein. The suppressive effect of whey protein in younger adults may be affected by having dietary restraints or actively trying to lose body weight $[33,34]$. Furthermore, the overall suppressive effect of protein supplements may be influenced by protein supplement intake before each meal of the day. The significant increase in cumulative protein intake and slight increase in cumulative energy intake in the older men suggests that whey protein can be given at breakfast, and possibly also at other meals, without decreasing overall daily energy intake, which would benefit malnourished, frail, older people-further studies are warranted. Another possible limitation was that the study was limited to $9 \mathrm{~h}$ after drink ingestion. As the effect of the pre breakfast drink on energy and protein intake had worn off by dinner, however, it seems unlikely that it would have had any effect after that.

\section{Conclusions}

Energy intake was suppressed by whey protein drinks in a protein load-responsive fashion at breakfast and particularly, at lunch, but not at dinner, and suppression of energy intake by protein was less in healthy older than younger men. Cumulative protein intake was increased in a protein load responsive fashion. These findings support the use of whey-protein drink supplements in healthy older patients who aim to increase their protein intake without decreasing their overall energy intake.

Author Contributions: C.G., A.C., and K.B. performed the study days; A.O., C.G., A.C., and K.L. analyzed the data; A.O., C.G., A.C., K.L.J., M.H., I.C., and S.S. interpreted the results; A.O., A.C., and K.B. drafted the manuscript; C.G., K.L., M.H., K.L.J., I.C., and S.S. edited and revised the manuscript; A.O., C.G., A.C., K.B., K.L., M.H., K.L.J., I.C., and S.S. approved the final version of the manuscript; K.L., M.H., I.C., and S.S. conception and design of the research. All authors have read and agreed to the published version of the manuscript.

Funding: This research was funded by Royal Adelaide Hospital Endocrine Unit Gum Bequest Grant. Royal Adelaide Hospital Research Foundation did not have any input in the design, implementation, analysis, or interpretation of the data. 
Acknowledgments: We thank Bulk Nutrients, Tasmania, Australia for providing whey protein and the members of the Centre of Clinical Research Excellence in Translating Nutritional Research to Good Health, Adelaide Medical School, The University of Adelaide, Royal Adelaide Hospital for all provided support during this study.

Conflicts of Interest: The authors declare no conflict of interest.

\section{References}

1. Leslie, W.; Hankey, C. Aging, nutritional status and health. Healthcare 2015, 3, 648-658. [CrossRef] [PubMed]

2. Soenen, S.; Chapman, I.M. Body weight, anorexia, and undernutrition in older people. J. Am. Med. Dir. Assoc. 2013, 14, 642-648. [CrossRef]

3. Giezenaar, C.; Chapman, I.; Luscombe-Marsh, N.; Feinle-Bisset, C.; Horowitz, M.; Soenen, S. Ageing is associated with decreases in appetite and energy intake-A meta-analysis in healthy adults. Nutrients 2016, 8, 28. [CrossRef] [PubMed]

4. Siparsky, P.N.; Kirkendall, D.T.; Garrett, W.E., Jr. Muscle changes in aging: Understanding sarcopenia. Sports Health 2014, 6, 36-40. [CrossRef] [PubMed]

5. Soenen, S.; Rayner, C.K.; Horowitz, M.; Jones, K.L. Gastric emptying in the elderly. Clin. Geriatr. Med. 2015, 31, 339-353. [CrossRef] [PubMed]

6. Soenen, S.; Rayner, C.K.; Jones, K.L.; Horowitz, M. The ageing gastrointestinal tract. Curr. Opin. Clin. Nutr. Metab. Care. 2016, 19, 12-18. [CrossRef] [PubMed]

7. Cawood, A.; Elia, M.; Stratton, R. Systematic review and meta-analysis of the effects of high protein oral nutritional supplements. Ageing Res. Rev. 2012, 11, 278-296. [CrossRef] [PubMed]

8. Malafarina, V.; Uriz-Otano, F.; Iniesta, R.; Gil-Guerrero, L. Effectiveness of nutritional supplementation on muscle mass in treatment of sarcopenia in old age: A systematic review. J. Am. Med. Dir. Assoc. 2013, 14, 10-17. [CrossRef]

9. Soenen, S.; Giezenaar, C.; Hutchison, A.T.; Horowitz, M.; Chapman, I.; Luscombe-Marsh, N.D. Effects of intraduodenal protein on appetite, energy intake, and antropyloroduodenal motility in healthy older compared with young men in a randomized trial. Am. J. Clin. Nutr. 2014, 100, 1108-1115. [CrossRef]

10. Giezenaar, C.; Coudert, Z.; Baqeri, A.; Jensen, C.; Hausken, T.; Horowitz, M.; Chapman, I.; Soenen, S. Effects of timing of whey protein intake on appetite and energy intake in healthy older men. J. Am. Med. Dir. Assoc. 2017, 18, 898.e9-898.e13. [CrossRef]

11. Giezenaar, C.; Trahair, L.G.; Rigda, R.; Hutchison, A.T.; Feinle-Bisset, C.; Luscombe-Marsh, N.D.; Hausken, T.; Jones, K.L.; Horowitz, M.; Chapman, I.; et al. Lesser suppression of energy intake by orally ingested whey protein in healthy older men compared with young controls. Am. J. Physiol. Regul. Integr. Comp. Physiol. 2015, 309, R845-R854. [CrossRef] [PubMed]

12. Keri, M.N. Therapeutic applications of whey protein. Altern. Med. Rev. 2004, 9, 136-156.

13. Smithers, G.W. Whey and whey proteins-From 'gutter-to-gold'. Int. Dairy J. 2008, 18, 695-704. [CrossRef]

14. Hveem, K.; Jones, K.; Chatterton, B.; Horowitz, M. Scintigraphic measurement of gastric emptying and ultrasonographic assessment of antral area: Relation to appetite. Gut 1996, 38, 816-821. [CrossRef] [PubMed]

15. Parker, B.A.; Sturm, K.; MacIntosh, C.G.; Feinle, C.; Horowitz, M.; Chapman, I.M. Relation between food intake and visual analogue scale ratings of appetite and other sensations in healthy older and young subjects. Eur. J. Clin. Nutr. 2004, 58, 212-218. [CrossRef]

16. Rayner, C.K.; MacIntosh, C.G.; Chapman, I.M.; Morley, J.E.; Horowitz, M. Effects of age on proximal gastric motor and sensory function. Scand. J. Gastroenterol. 2000, 35, 1041-1047.

17. Giezenaar, C.; Lange, K.; Hausken, T.; Jones, K.L.; Horowitz, M.; Chapman, I.; Soenen, S. Effects of Age on Acute Appetite-Related Responses to Whey-Protein Drinks, Including Energy Intake, Gastric Emptying, Blood Glucose, and Plasma Gut Hormone Concentrations-A Randomized Controlled Trial. Nutrients 2020, 12, 1008. [CrossRef] 
18. Giezenaar, C.; Trahair, L.G.; Luscombe-Marsh, N.D.; Hausken, T.; Standfield, S.; Jones, K.L.; Lange, K.; Horowitz, M.; Chapman, I.; Soenen, S. Effects of randomized whey-protein loads on energy intake, appetite, gastric emptying, and plasma gut-hormone concentrations in older men and women. Am. J. Clin. Nutr. 2017, 106, 865-877. [CrossRef]

19. Giezenaar, C.; Van Der Burgh, Y.; Lange, K.; Hatzinikolas, S.; Hausken, T.; Jones, K.L.; Horowitz, M.; Chapman, I.; Soenen, S. Effects of Substitution, and Adding of Carbohydrate and Fat to Whey-Protein on Energy Intake, Appetite, Gastric Emptying, Glucose, Insulin, Ghrelin, CCK and GLP-1 in Healthy Older Men-A Randomized Controlled Trial. Nutrients 2018, 10, 113. [CrossRef]

20. Hutchison, A.T.; Piscitelli, D.; Horowitz, M.; Jones, K.L.; Clifton, P.M.; Standfield, S.; Hausken, T.; Feinle-Bisset, C.; Luscombe-Marsh, N.D. Acute load-dependent effects of oral whey protein on gastric emptying, gut hormone release, glycemia, appetite, and energy intake in healthy men. Am. J. Clin. Nutr. 2015, 102, 1574-1584. [CrossRef]

21. Sturm, K.; Parker, B.; Wishart, J.; Feinle-Bisset, C.; Jones, K.L.; Chapman, I.; Horowitz, M. Energy intake and appetite are related to antral area in healthy young and older subjects. Am. J. Clin. Nutr. 2004, 80, 656-667. [CrossRef] [PubMed]

22. Giezenaar, C.; Hutchison, A.T.; Luscombe-Marsh, N.D.; Chapman, I.; Horowitz, M.; Soenen, S. Effect of age on blood glucose and plasma insulin, glucagon, ghrelin, CCK, GIP, and GLP-1 responses to whey protein ingestion. Nutrients 2017, 10, 2. [CrossRef]

23. Janssen, P.; Vanden, B.P.; Verschueren, S.; Lehmann, A.; Depoortere, I.; Tack, J. The role of gastric motility in the control of food intake. Aliment. Pharmacol. Ther. 2011, 33, 880-894. [CrossRef] [PubMed]

24. Jones, K.L.; Doran, S.M.; Hveem, K.; Bartholomeusz, F.D.; E Morley, J.; Sun, W.M.; E Chatterton, B.; Horowitz, M. Relation between postprandial satiation and antral area in normal subjects. Am. J. Clin. Nutr. 1997, 66, 127-132. [CrossRef]

25. E Rigamonti, A.; Leoncini, R.; Casnici, C.; Marelli, O.; De Col, A.; Tamini, S.; Lucchetti, E.; Cicolini, S.; Abbruzzese, L.; Cella, S.; et al. Whey Proteins Reduce Appetite, Stimulate Anorexigenic Gastrointestinal Peptides and Improve Glucometabolic Homeostasis in Young Obese Women. Nutrients 2019, 11, 247. [CrossRef] [PubMed]

26. Paddon, J.D.; Leidy, H. Dietary protein and muscle in older persons. Curr. Opin. Clin. Nutr. Metab. Care 2014, 17, 5. [CrossRef]

27. Rolls, B.J.; Dimeo, K.A.; Shide, D.J. Age-related impairments in the regulation of food intake. Am. J. Clin. Nutr. 1995, 62, 923-931. [CrossRef]

28. Giezenaar, C.; Luscombe-Marsh, N.D.; Hutchison, A.T.; Lange, K.; Hausken, T.; Jones, K.L.; Horowitz, M.; Chapman, I.; Soenen, S. Effect of gender on the acute effects of whey protein ingestion on energy intake, appetite, gastric emptying and gut hormone responses in healthy young adults. Nutr. Diabetes 2018, 8, 40. [CrossRef]

29. Wurtman, J.J.; Lieberman, H.; Tsay, R.; Nader, T.; Chew, B. Calorie and nutrient intakes of elderly and young subjects measured under identical conditions. J. Gerontol. 1988, 43, B174-B180. [CrossRef]

30. Clarkston, W.; Pantano, M.; Morley, J.; Horowitz, M.; Littlefield, J.; Burton, F. Evidence for the anorexia of aging: Gastrointestinal transit and hunger in healthy elderly vs. young adults. Am. J. Physiol. Regul. Integr. Comp. Physiol. 1997, 272, R243-R248. [CrossRef]

31. Sturm, K.; MacIntosh, C.G.; Parker, B.A.; Wishart, J.; Horowitz, M.; Chapman, I.M. Appetite, food intake, and plasma concentrations of cholecystokinin, ghrelin, and other gastrointestinal hormones in undernourished older women and well-nourished young and older women. J. Clin. Endocrinol. Metab. 2003, 88, 3747-3755. [CrossRef] [PubMed]

32. Roberts, S.B.; Fuss, P.; Heyman, M.B.; Evans, W.J.; Tsay, R.; Rasmussen, H.; Fiatarone, M.; Cortiella, J.; Dallal, G.E.; Young, V.R. Control of food intake in older men. JAMA 1994, 272, 1601-1606. [CrossRef] [PubMed] 
33. Griffin, H.; Cheng, H.; O'connor, H.; Rooney, K.; Petocz, P.; Steinbeck, K. Higher protein diet for weight management in young overweight women: A 12-month randomized controlled trial. Diabetes. Obes. Metab. 2013, 15, 572-575. [CrossRef] [PubMed]

34. Leidy, H.J.; Carnell, N.S.; Mattes, R.D.; Campbell, W.W. Higher protein intake preserves lean mass and satiety with weight loss in pre-obese and obese women. Obesity 2007, 15, 421-429. [CrossRef]

Publisher's Note: MDPI stays neutral with regard to jurisdictional claims in published maps and institutional affiliations.

(C) 2020 by the authors. Licensee MDPI, Basel, Switzerland. This article is an open access article distributed under the terms and conditions of the Creative Commons Attribution (CC BY) license (http://creativecommons.org/licenses/by/4.0/). 